\title{
Effect of age on the dimensions and shape of spermatozoa of Large White Polish boars
}

\author{
Dorota Banaszewska, Stanisław Kondracki and Anna Wysokińska
}

Department of Animal Reproduction and Hygiene, Institute of Bioengineering and Animal Breeding, University of a Natural Sciences and Humanities in Siedlce, Siedlce, Poland

\begin{abstract}
Studies were conducted on 190 ejaculates collected from 16 Large White Polish boars, 7-8 months old. In order to examine spermatozoa morphology, an ejaculate sample was taken from boar monthly microscopic slides were prepared. In each preparation morphometric measurements were taken of fifteen randomly selected spermatozoa, using a computer image analysis software (Screen Measurement v. 4.1), to determine basic sperm dimensions and morphology parameters. Moreover, evaluation of frequency of spermatozoa morphological abnormalities was made. It was found that boar age was associated with sperm dimensions and shape. As boars grew older, sperm length, width and head area increased. However, young boars, under 11 months old, had slightly longer spermatozoa than older boars, in terms of both the length of the whole spermatozoon and the length of the flagellum. The spermatozoa's morphological build indicators show that boars aged 16 months approx possess semen that is characterised by an elongated head. This assertion is based on the proportions between the head's width and its length. This proportion proved to be smaller when compared to that present in the sperm of boars over the age of 17 months $(P \leq 0.01)$.
\end{abstract}

Keywords: boar, sperm, age, morphometry

\section{Zusammenfassung}

\section{Der Einfluss des Alters auf Parameter und Gestalt der Spermien von polnischen Edelschweinebern}

Untersucht wurden 190 Ejakulate, die von 16 polnischen Edelschweinebern im Alter von 7-8 Monaten gewonnen wurden. Monatlich wurde eine Ejakulatprobe zur Bestimmung der Spermienmorphologie entnommen. Von diesen Proben wurden mikroskopische Präparate erstellt und morphometrische Messungen an 15 zufällig gewählten Spermien mittels computergestützter Bildanalyse (Screen Measurement v. 4.1) durchgeführt. Dabei wurde ein Zusammenhang zwischen dem Alter des Ebers sowie Größe und Form der Spermien nachgewiesen. Mit zunehmenden Alter der Eber wurde der Spermienkopf größer. Allerdings waren die Spermien von jungen Ebern im Alter bis zu 11 Monaten etwas länger (sowohl Gesamtlänge als auch Geißel) als die von älteren Zuchttieren. Spermien der jungen Eber im Alter bis etwa 16 Monaten haben eine verlängerte Gestalt des Spermienkopfes. Darauf deutet das geringere Verhältnis der Breite des Spermienkopfes zur Länge des Spermienkopfes im 
Vergleich mit Ejakulaten, die von den Ebern im Alter von mehr als 17 Monaten gewonnen wurden $(P \leq 0.01)$, hin.

Schlüsselwőrter: Eber, Spermium, Alter, Morphometrie

\section{Introduction}

In Polish animal fertilization centres, boars begin to be utilized at 7-8 months of age. Such animals are already sexually mature although they reach their full reproductive potential much later. As a male continues to develop sexually, the quality of its sperm usually improves (Bertani et al. 2002, Clark et al. 2003, Kondracki et al. 2004, Banaszewska 2004), just like physical ejaculate parameters (Flowers 2008). It is associated with the development of internal structure of testicles and accessory sexual glands, as well as increasing sperm epididymal reserves (Kumaresan et al. 2011). Thus, sexual development of boars does not terminate at a certain age but continues although the rate of the development of boar reproductive system is much slower at a later age (Banaszewska 2004). The microscopic examination of the spermatozoa's morphology may serve as preliminary assessment of the sperm's ability to transfer genetic material. It also delivers valuable information of the spermatozoa's quality and enables allows the diagnosis of many forms of build disorders, which may contribute to the sperm's lower fertilisation capacity. Examination of sperm morphology also provides objective information on the frequency of spermatozoa unable to fertilize an ovum. In the sperm characterised by a high frequency of developmental abnormalities, the remaining spermatozoa, which seem to have normal morphology, may have limited fertilizing capacity. Damaged spermatozoa or apoptotic cells may be a source of toxic substances excreted to semen plasma which can also affect the remaining spermatozoa (Bronicka \& Dembiński 1999). Semen can also contain spermatozoa with normal morphology, motility and mitochondrial activity but their nuclei may have damaged chromatin. It results from sensitivity of chromatin to denaturation, which in consequence leads to apoptosis of reproductive cells. It was found that chromatin sensitivity to denaturation is a natural phenomenon occurring in sexually immature animals and later it disappears spontaneously (Karabinus et al. 1990). Developmental abnormalities may be linked to factors associated with disturbed spermatogenesis, environmental factors or personal predisposition of a male to produce semen with poorer quality. Moreover, they can be a result of a male's carrying genetic mutations. Frequency of sperm structural defects is also depended on a male's age (Crabo 1997, Šernienè et al. 2002, Banaszewska 2004, Kawęcka et al. 2008, Smital 2009). Computer-assisted sperm analysis, which makes it possible to measure individual sperm dimensions, is an important criterion of semen quality evaluation, too. The analysis enables experimenters to test subpopulations of spermatozoa with specific properties and evaluate their shape. Spermatozoa of individual animal species have got their standard and differ in terms of dimensions and shape (Cummins \& Woodall 1985). However, it has been demonstrated that there are differences in sperm dimensions in males within the same species or breed (Kondracki et al. 2005, Saravia et al. 2007, Hidalgo et al. 2008). Some studies have shown that there is an association of sperm dimensions and shape with male fertility (Gage \& Morrow 2003, Brito 2007). Male age is one of significant causes of variation in spermatozoa morphology and morphometric dimensions. Such a 
relationship has been deduced based on results of research demonstrating differences in sperm dimensions resulting from a male's age (Gregor \& Hardge 1995, Kondracki et al. 2005, Quintero-Moreno et al. 2009). So, it is fully justified to examine the effect of age on sperm dimensions and shape. The present work is an attempt to evaluate the influence the age of Large White Polish boars has on morphometric characteristics of spermatozoa in their ejaculates.

\section{Materials and methods}

Studies were conducted on 190 ejaculates obtained form 16 Large White Polish boars. All the animals were utilized at two stations owned by the Mazovian Centre of Animal Breeding and Reproduction in Łowicz. The boars were maintained in the station under uniform management conditions (housing, feeding and health care). The males were young, about 7-8 months of age, and they had not been utilized for reproduction yet. During the first 20 months of the chosen boars' reproductive activity, monthly ejaculate samples have been collected. The ejaculates were taken with the »gloved-hand « method (King \& Macpherson 1973) early in the morning and samples were taken from each ejaculate to prepare a microscopic slide used to take morphometric measurements of spermatozoa and determine frequency of sperm morphometric abnormalities.

Sperm morphometric measurements were taken from each boar and assessment of semen morphology was done on the basis of examination under a microscope of preparations made from fresh ejaculates. The method of slide preparation had been described in the previous work by Kondracki et al. (2006). The preparations were examined under the light microscope Nikon E-50i using 100x immersion lens. For each slide, morphometric measurements were taken of 15 randomly selected spermatozoa characterised by normal morphology and well visible under the microscope. The measurements were done by means of a computer image analysis software (Screen Measurement v. 4.1, Laboratory Imaging S.r.o. LIM Czech Republic) following methodology prepared by Kondracki et al. (2005). A total of 2850 measurements were taken. They included: sperm head perimeter, head area, sperm head length, sperm head width, flagellum length and overall sperm length. The following parameters of sperm morphology were calculated on the basis of the results of the morphometric measurements: sperm head width/length ratio, head length/overall sperm length ratio and sperm head length/flagellum length ratio.

Additionally, in each preparation morphometry of 500 spermatozoa was evaluated, numbers of spermatozoa with normal morphology and morphological abnormalities were recorded and these were categorized into spermatozoa with major and minor abnormalities following the Blom classification system (Blom 1981).

The results were grouped according to the criterion of boar age on semen collection day. The first sub-group contained data on ejaculates collected from boars at least 8 months old. Each subsequent sub-group included data for semen evaluation of boars one month older. The results were statistically analysed by means of variance analysis. Group mean separation was obtained by Tukey's test. 


\section{Results}

Table 1 covers data on sperm morphometric dimensions according to boar age. They demonstrate that boar age influenced sperm morphometric characteristics. In particular, dynamic changes were observed as regards increases in the sperm head length and width of growing boars. Sperm head length increased from $8.88 \mu \mathrm{m}$ at 8 months of age to $9.37 \mu \mathrm{m}$ at the age of 24 months. Sperm head width increased from 4.60 to $5.13 \mu \mathrm{m}$ for boars, respectively 8 and 23 months old, the increase being $0.5 \mu \mathrm{m}(P \leq 0.01)$. As boars grow, their spermatozoa seem to have larger heads, as reflected by increasing values for sperm head length, width and perimeter. Sperm heads of boars 8 months old had perimeter equalling $23.38 \mu \mathrm{m}$ whereas in the ejaculates of boars 27 months old the value was by almost $1 \mu \mathrm{m}$ greater and amounted to $24.27 \mu \mathrm{m}$. By contrast, with increased age, the length of boar sperm flagellum decreased. The sperm of young boars, about 10 months old, had slightly longer flagella (approximately $44.46 \mu \mathrm{m}$ ) than the sperm from ejaculates of older males. Spermatozoa collected from boars 26 months old had a flagellum $42.76 \mu \mathrm{m}$ long, which was by around $2 \mu \mathrm{m}$ shorter. However, the differences were not statistically significant.

Table 1

Morphometric traits of sperms depending on the age of boar

\begin{tabular}{|c|c|c|c|c|c|c|c|}
\hline $\begin{array}{l}\text { Age } \\
\text { of boar, } \\
\text { month }\end{array}$ & $\begin{array}{l}\text { Sperm head } \\
\text { length, } \mu \mathrm{m}\end{array}$ & $\begin{array}{l}\text { Sperm head } \\
\text { width, } \mu \mathrm{m}\end{array}$ & $\begin{array}{c}\text { Sperm head } \\
\text { perimeter, } \mu \mathrm{m}\end{array}$ & $\begin{array}{l}\text { Sperm head } \\
\text { area, } \mu \mathrm{m}^{2}\end{array}$ & $\begin{array}{l}\text { Sperm tail } \\
\text { length, } \mu \mathrm{m}\end{array}$ & $\begin{array}{l}\text { Total sperm } \\
\text { length, } \mu \mathrm{m}\end{array}$ & $\begin{array}{c}\text { No of } \\
\text { ejaculates }\end{array}$ \\
\hline$\leq 8$ & $8.88 \pm 0.40$ & $4.60 \pm 0.90$ & $23.38 \pm 0.92$ & $37.95 \pm 4.09$ & $44.17 \pm 0.85$ & $53.05 \pm 1.12$ & 9 \\
\hline 9 & $8.74 \pm 0.20$ & $4.52 \pm 0.11$ & $23.08 \pm 0.51$ & $37.24 \pm 2.62$ & $43.91 \pm 1.13$ & $52.65 \pm 1.08$ & 9 \\
\hline 10 & $9.12 \pm 0.39$ & $4.66 \pm 0.22$ & $23.79 \pm 0.88$ & $41.18 \pm 3.14$ & $44.46 \pm 1.14$ & $53.57 \pm 1.27$ & 11 \\
\hline 11 & $9.06 \pm 0.33$ & $4.62 \pm 0.11$ & $23.63 \pm 0.77$ & $40.60 \pm 3.85$ & $44.09 \pm 1.20$ & $53.14 \pm 1.51$ & 8 \\
\hline 12 & $9.13 \pm 0.33$ & $4.72 \pm 0.12$ & $24.00 \pm 0.78$ & $41.51 \pm 3.14$ & $43.56 \pm 1.76$ & $52.69 \pm 1.88$ & 11 \\
\hline 13 & $9.04 \pm 0.31$ & $4.73 \pm 0.21$ & $23.43 \pm 0.65$ & $39.65 \pm 2.86$ & $43.42 \pm 0.89$ & $52.45 \pm 1.10$ & 12 \\
\hline 14 & $9.10 \pm 0.32$ & $4.73 \pm 0.24$ & $23.67 \pm 0.85$ & $40.51 \pm 3.67$ & $43.59 \pm 0.99$ & $52.69 \pm 1.21$ & 13 \\
\hline 15 & $9.08 \pm 0.52$ & $4.65 \pm 0.37$ & $23.51 \pm 1.18$ & $39.91 \pm 3.76$ & $43.71 \pm 0.99$ & $52.78 \pm 1.46$ & 7 \\
\hline 16 & $9.17 \pm 0.36$ & $4.73 \pm 0.30$ & $23.68 \pm 0.87$ & $40.41 \pm 3.35$ & $43.62 \pm 1.34$ & $52.79 \pm 1.61$ & 13 \\
\hline 17 & $9.14 \pm 0.37$ & $4.82 \pm 0.30$ & $23.61 \pm 0.73$ & $39.49 \pm 2.25$ & $43.06 \pm 0.86$ & $52.20 \pm 0.74$ & 11 \\
\hline 18 & $9.23 \pm 0.30$ & $4.88 \pm 0.30$ & $23.70 \pm 0.51$ & $39.36 \pm 2.85$ & $43.58 \pm 0.75$ & $52.81 \pm 0.74$ & 9 \\
\hline 19 & $9.15 \pm 0.33$ & $4.91 \pm 0.32$ & $23.69 \pm 0.84$ & $39.44 \pm 2.99$ & $43.67 \pm 1.00$ & $52.82 \pm 1.16$ & 15 \\
\hline 20 & $9.12 \pm 0.17$ & $4.84 \pm 0.36$ & $23.42 \pm 0.82$ & $38.62 \pm 3.03$ & $43.68 \pm 1.25$ & $52.80 \pm 1.32$ & 9 \\
\hline 21 & $9.19 \pm 0.30$ & $5.04 \pm 0.19$ & $23.76 \pm 0.75$ & $39.70 \pm 3.23$ & $43.89 \pm 1.42$ & $53.07 \pm 1.29$ & 7 \\
\hline 22 & $9.24 \pm 0.31$ & $4.96 \pm 0.36$ & $23.98 \pm 1.09$ & $39.97 \pm 3.36$ & $43.21 \pm 1.38$ & $52.46 \pm 1.50$ & 14 \\
\hline 23 & $9.32 \pm 0.26$ & $5.13 \pm 0.32$ & $23.79 \pm 1.27$ & $40.18 \pm 2.56$ & $43.17 \pm 1.35$ & $52.49 \pm 1.32$ & 7 \\
\hline 24 & $9.37 \pm 0.26$ & $5.03 \pm 0.20$ & $24.04 \pm 0.36$ & $41.05 \pm 2.09$ & $43.36 \pm 0.91$ & $52.73 \pm 0.95$ & 6 \\
\hline 25 & $9.26 \pm 0.47$ & $5.01 \pm 0.32$ & $23.57 \pm 1.14$ & $39.54 \pm 3.81$ & $43.34 \pm 0.82$ & $52.60 \pm 0.61$ & 6 \\
\hline 26 & $9.35 \pm 0.70$ & $5.16 \pm 0.13$ & $23.99 \pm 0.29$ & $41.80 \pm 0.78$ & $42.76 \pm 1.39$ & $52.11 \pm 1.33$ & 3 \\
\hline 27 & $9.36 \pm 0.19$ & $4.88 \pm 0.53$ & $24.27 \pm 0.68$ & $39.97 \pm 4.58$ & $43.93 \pm 2.25$ & $53.23 \pm 2.12$ & 3 \\
\hline 28 & $9.35 \pm 0.13$ & $4.67 \pm 0.16$ & $23.58 \pm 0.60$ & $41.95 \pm 1.79$ & $43.21 \pm 1.46$ & $52.56 \pm 1.57$ & 7 \\
\hline $\mathrm{LSD}_{0.05}$ & 0.533 & 0.435 & 1.364 & 5.121 & 1.930 & 2.136 & \\
\hline $\mathrm{LSD}_{0.01}$ & 0.602 & 0.491 & 1.541 & 5.787 & 2.181 & 2.413 & \\
\hline
\end{tabular}

LSD: least significant differences

The spermatozoa's morphological build indicators show that boars aged 16 months approx possess semen that is characterised by an elongated head. This assertion is based on the proportions between the head's width and its length. This proportion proved to be smaller 


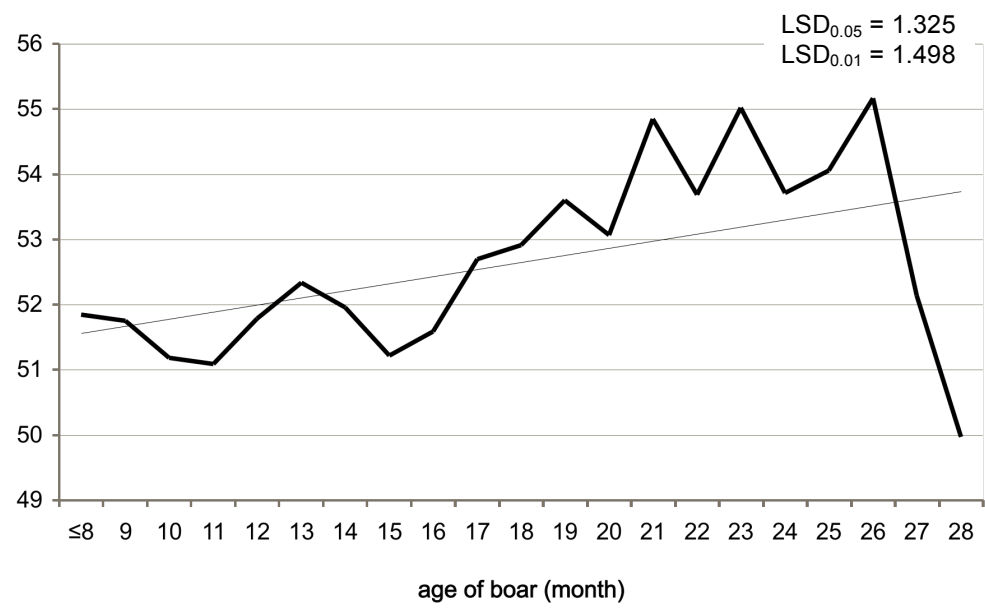

Figure 1

Width to length

of sperm head

depending on the age of boar

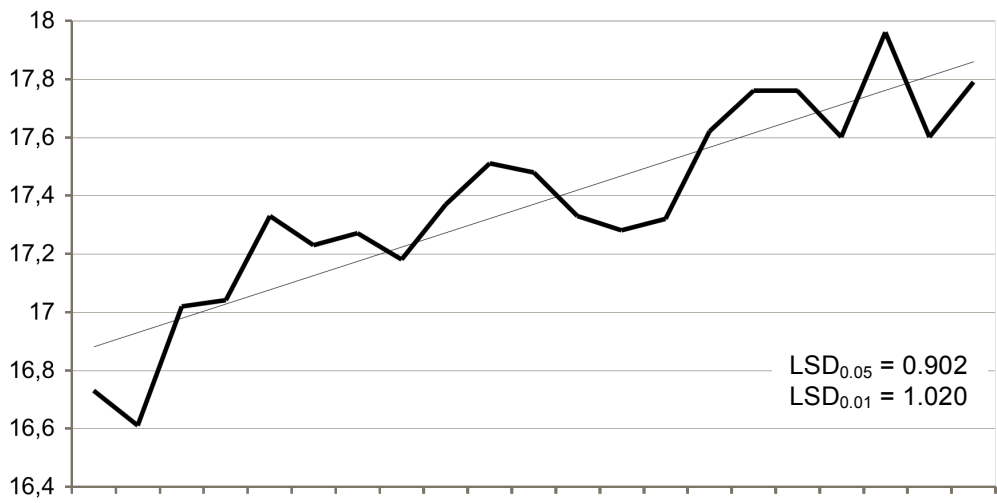

$\begin{array}{lllllllllllllllllllll}\leq 8 & 9 & 10 & 11 & 12 & 13 & 14 & 15 & 16 & 17 & 18 & 19 & 20 & 21 & 22 & 23 & 24 & 25 & 26 & 27 & 28\end{array}$

age of boar (month)

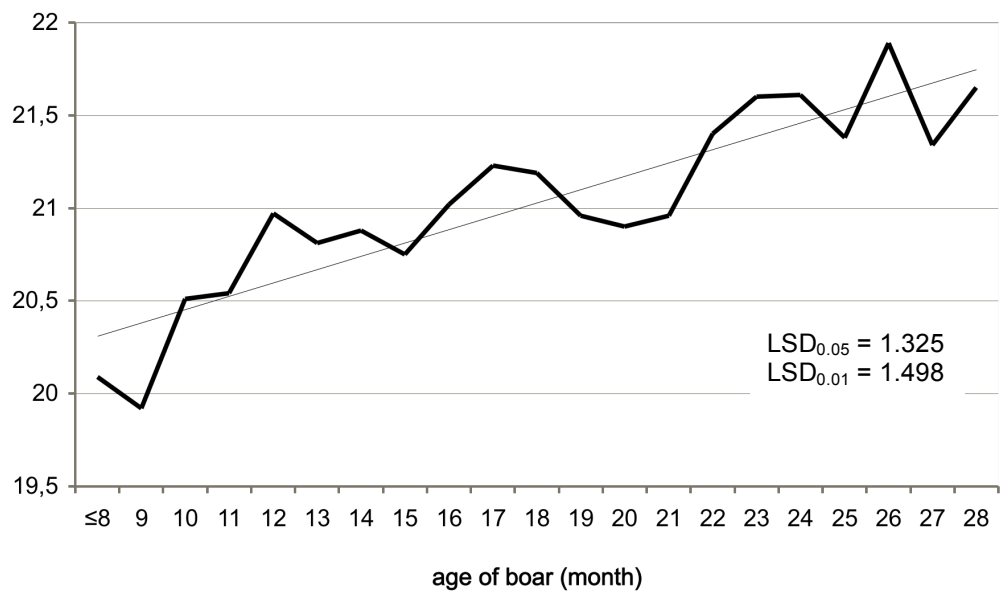

Figure 2

Ratio of head length of sperm to total sperm length depending on the age of boar

Figure 3

Ratio of head length of sperm to sperm tail length depending on the age of boar

age of boar (month) 
when compared to that present in the sperm of boars over the age of 17 months $(P \leq 0.01)$ (Figure 1).

The results indicate that the sperm heads of young males were longer. Spermatozoa of young boars, less than 9 months of age, which had only begun to be used for reproduction, were longer than the sperm of boars about 17 months old as indicated by a lower ratio of sperm head length to flagellum length and to the overall sperm length $(P \leq 0.05)$ (Figure 2, 3). Table 2 demonstrates data on frequency of spermatozoa with morphological defects in the sperm of Large White Polish boars according to their age. The ejaculates studied were of good quality irrespective of the age of boars as there was a low frequency of sperm morphological abnormalities, which did not exceed $9 \%$, and a small percentage of spermatozoa with primary morphological changes (under 2.6\%). No significant between-group differences were found for primary sperm morphological defects whereas for secondary defects the differences were small and insignificant in most cases. Only in ejaculates collected at 21 months of age, the average frequency of secondary morphological defects was slightly higher $(11.43 \%)$, which resulted from a high frequency of these defects in two ejaculates and seemed to be due to chance only.

Table 2

Frequency of occurrence of spermatozoas morphologically changed depending on the age of boar

\begin{tabular}{|c|c|c|c|c|}
\hline $\begin{array}{l}\text { Age of } \\
\text { boar, month }\end{array}$ & $\begin{array}{c}\text { Normal } \\
\text { spermatozoa, } \%\end{array}$ & $\begin{array}{c}\text { Sperm with } \\
\text { major abnormalities, \% }\end{array}$ & $\begin{array}{c}\text { Sperm with } \\
\text { minor abnormalities, \% }\end{array}$ & $\begin{array}{l}\text { Number of } \\
\text { ejaculates }\end{array}$ \\
\hline$\leq 8$ & $97.00 \pm 2.74$ & $0.69 \pm 0.64$ & $2.42 \pm 2.59$ & 9 \\
\hline 9 & $96.69 \pm 5.13$ & $0.96 \pm 1.75$ & $2.36 \pm 3.48$ & 9 \\
\hline 10 & $97.20 \pm 2.71$ & $0.82 \pm 1.58$ & $1.98 \pm 2.66$ & 11 \\
\hline 11 & $95.20 \pm 3.57$ & $0.55 \pm 0.81$ & $4.25 \pm 3.14$ & 8 \\
\hline 12 & $96.65 \pm 4.27$ & $0.69 \pm 1.00$ & $2.65 \pm 4.21$ & 11 \\
\hline 13 & $91.62 \pm 7.94$ & $2.57 \pm 4.69$ & $5.38 \pm 7.45$ & 12 \\
\hline 14 & $95.60 \pm 3.21$ & $1.32 \pm 1.80$ & $2.94 \pm 1.98$ & 13 \\
\hline 15 & $98.00 \pm 2.07$ & $0.40 \pm 0.45$ & $1.63 \pm 1.68$ & 7 \\
\hline 16 & $96.66 \pm 3.63$ & $0.80 \pm 0.96$ & $2.54 \pm 2.73$ & 13 \\
\hline 17 & $94.33 \pm 5.05$ & $0.76 \pm 0.77$ & $3.73 \pm 4.01$ & 11 \\
\hline 18 & $95.24 \pm 4.35$ & $0.58 \pm 0.61$ & $4.07 \pm 4.25$ & 9 \\
\hline 19 & $92.00 \pm 9.40$ & $1.95 \pm 2.54$ & $5.71 \pm 7.55$ & 15 \\
\hline 20 & $96.48 \pm 3.14$ & $0.49 \pm 0.76$ & $3.06 \pm 2.89$ & 9 \\
\hline 21 & $86.75 \pm 19.35$ & $2.26 \pm 3.33$ & $11.43 \pm 16.12$ & 7 \\
\hline 22 & $92.84 \pm 7.91$ & $2.23 \pm 3.47$ & $4.93 \pm 4.81$ & 14 \\
\hline 23 & $93.23 \pm 7.18$ & $1.49 \pm 2.23$ & $5.29 \pm 5.25$ & 7 \\
\hline 24 & $96.73 \pm 2.36$ & $0.83 \pm 0.92$ & $2.43 \pm 1.55$ & 6 \\
\hline 25 & $95.83 \pm 1.86$ & $0.73 \pm 0.58$ & $3.43 \pm 1.43$ & 6 \\
\hline 26 & $91.00 \pm 6.24$ & $1.33 \pm 0.81$ & $7.67 \pm 5.43$ & 3 \\
\hline 27 & $92.47 \pm 7.84$ & $1.00 \pm 0.92$ & $6.53 \pm 6.97$ & 3 \\
\hline 28 & $91.89 \pm 7.01$ & $2.09 \pm 2.67$ & $6.00 \pm 4.61$ & 7 \\
\hline $\mathrm{LSD}_{0.05}$ & 10.638 & 3.466 & 8.596 & \\
\hline $\mathrm{LSD}_{0.01}$ & 12.021 & 3.916 & 9.713 & \\
\hline
\end{tabular}

LSD: least significant differences 


\section{Discussion}

Juvenile boars continue to develop sexually even if they reach the age when they attain sexual maturity as indicated by changing sperm dimensions and shape of Large White Polish boars examined in the present study. With age, boar sperm heads lengthened and widened until 2 years of age, the finding similar to the studies by Kondracki et al. (2005) who have reported that sexually mature males of domestic pig have spermatozoa with larger heads compared with young boars. Quintero-Moreno et al. (2009) have also suggested that sperm head dimensions change as pigs develop sexually. Younger boars, under 1.5 years of age, had spermatozoa with a smaller perimeter and a lower head area compared with older males. It was also found that sperm heads of boars over 18 months old were longer and narrower than sperm heads in the semen of young boars, under 18 months old. The above findings indicate that the sperm heads were elongated in older animals (Quintero-Moreno et al. 2009) which, however, was not confirmed in the present study as more elongated spermatozoa were determined in the sperm of young boars up to 9 months of age.

The size and shape of spermatozoa are conditioned by the size of nucleus, which is located in the main part of the sperm head, and acrosome shape and dimensions. Some authors point out that even subtle changes in the sperm head shape may be associated with chromatin structure changes in the nucleus (Sailer et al. 1996), which may lead to poorer fertility (Evenson \& Wixon 2006). According to Hirai et al. (2001), highly fertile boars have spermatozoa with smaller and shorter heads compared with boars with lower fertilization efficiency. As a result, many authors link sperm head dimensions to fertility in humans (Ombelet et al. 1995, Azis et al. 1998), stallions (Casey et al. 1997, Brito 2007) pigs and wild boars (Hirai et al. 2001, Thurston et al. 2001, Quintero-Moreno et al. 2009); and head shape to sperm velocity (Malo et al. 2006) because sperm motility is a basic indicator of fertilization efficiency. It is widely assumed that a high percentage of progressively motile spermatozoa is a basic indicator of boar's fecundity. Motility of a spermatozoon may be influenced by the size of its head. It can be speculated that smaller heads make it easier for sperm to move and increase their chance of reaching the ovum. There are some works which confirm that there is an association between sperm dimensions and the level of their competitiveness while in the female genital tract (Gomendio \& Roldan 1991, Gage \& Cook 1994). Studies of some authors have shown differences as to the intensity and forms of sperm movement according to head shape (Thurston et al. 2001).

Radwan (1996) has ascertained that there is a positive association between the overall sperm length and fertilization efficiency. The overall sperm length is an indicator of competition while reaching the place where spermatozoa are stored in the female reproductive tract, and sperm with a longer flagellum can cover the distance to the ovum faster and with higher dynamics of flagellar motility. Longer spermatozoa can move more actively and, at the same time, they more rapidly use the energy and undergo apoptosis (Gomendio \& Roldan 1991, 1993). According to GIL et al. (2009), spermatozoa with higher values for ellipticity (head length/head width) and wider mid-pieces are less able to exhibit rapid linear progression. Anderson \& Dixon (2002) have suggested that mid-piece length reflects the size of the mitochondrial spiral, which affects the amounts of energy produced which is necessary for optimal sperm motility. Spermatozoa are elongated and hydrodynamic in shape, which is likely to positively influence the effectiveness of traversing the female genital tract. 
Results from this study showed changes in sperm dimensions taking place with increased age of boars. The semen of younger boars contained sperm with smaller heads but with longer flagella. It is possible that as sexual maturity of a male progresses, sperm morphology traits develop. Ejaculates of young boars are characterised by substantial variation and, although semeniferous epithelium efficiency stabilizes at about 7 months of age, sperm morphology and shape are less variable when a male reaches the age of around 11-12 months (Kondracki et al. 2005). Some authors have suggested that variation in sperm dimensions may result from the advancement of sperm maturation in the epididymal duct (Thurston et al. 2001, Peña et al. 2005) because while spermatozoa are swimming through the epididymal duct, the normal chromatin structure is being formed.

Sperm quality plays a very important role in male fertility and reproductive performance. Sperm morphometry and sperm dimensions and shape which are associated with the morphology are indicators of sperm quality. Together with sperm ultrastructure characteristics, they reflect the fertilizing capacity of male sperm. It has been demonstrated that spermatozoa with abnormal morphology present in semen are associated with diminished male fecundity (Shamsuddin et al. 1993). Morphologically altered spermatozoa are unable to reach the ovum (Shamsuddin \& Rodríguez-Martínez 1994). Some studies have shown that diminished sperm motility is associated with a high frequency of spermatozoa with abnormal morphology (Šernienè et al. 2002). The semen of White Lithuanian boars collected at 10-18 months of age was found to contain less motile spermatozoa and more morphologically altered spermatozoa compared with Pietrain boars at the same age (Šernienè et al. 2002).

Male age is one of factors affecting the frequency of sperm morphological defects. However, analysis of this frequency according to male age provides ambiguous results. Data presented in this work allow us to distinguish no obvious trends of changes in the morphological image of semen taking place with age. The semen of juvenile boars was characterised by good quality and contained less spermatozoa with primary defects. With age the frequency of boar sperm morphological abnormalities changes but they are irregular in character. It was found that the frequency of spermatozoa with abnormal morphology was higher in younger boars (Jacyno et al. 2009) whereas the percentage of morphologically altered spermatozoa decreased in older males (Kawęcka 2002, Banaszewska 2004). Some studies have shown that sperm morphology changes substantially with age. Moreover, there are observed more cases of some morphological defects in certain age intervals (Hallap et al. 2005, Al-Makhzoomi et al. 2008, Sarder 2008). Spermatozoa with pear-like heads were most frequent in the sperm of young boars prior to 1 year of age whereas coiled tails were the most frequent defect in the sperm of older boars, more than 30 months of age (Jankevičiūte \& Žilinskas 2002). The other studies have shown that spermatozoa with a proximal protoplasmic droplet on the mid-piece and a "pseudo-droplet « defects were detected in the semen of youngest boars, up to around 12 months of age (Banaszweska 2004). Also observed a higher percentage of spermatozoa with a defected acrosome in older boars compared with younger males (Quintero-Moreno et al. 2009). Ferrari et al. (1998) reported a positive correlation between a disturbed chromatin structure and some morphological abnormalities, for example, a narrower neck or a pearlike head. There are also some works reporting no distinct differences in the frequency of morphologically defected spermatozoa depending on boar age (Kondracki et al. 2005). 
To sum up, the age of sexually mature domestic male pigs had a significant effect on the morphometric traits of their spermatozoa. Older boars have got spermatozoa with longer and wider heads but shorter flagella. There is a clear correlation between the age of the boar upon the day sperm was collected and the shape and proportion of the spermatozoa. This indicates shape variations between existing gametes. No distinct tendencies were found as to the frequency of major and minor morphological defects of boar spermatozoa occurring with age.

\section{References}

Al-Makhzoomi A, Lundeheim N, Håård M, Rodríquez-Martínez H (2008) Sperm morphology and fertility of progeny-tested Al dairy bulls in Sweden. Theriogenology 70, 682-691

Anderson MJ, Dixon AF (2002) Sperm competition: motility and midpiece in primates. Nature 416, 496

Azis N, Fear S, Taylor C, Kingsland CR, Lewis-Jones I (1998) Human sperm head morphometric distribution and its influence on human fertility. Fertil Steril 70, 883-891

Banaszewska D (2004) Estimation of breeding's maturities and usefulnesses to insemination of boars of different breeds on basis of changes of quality ejaculates. Doctoral Thesis AP Siedlce, Poland [in Polish]

Bertani GR, Scheid IR, Irgang R, Barioni W Jr, Wentz I, Afonso SB (2002) Gonadal sperm reserve in purebred Landrace and Large White boars of high average daily gain. Theriogenology 57, 859-867

Blom E (1981) Studies on seminal vesiculitis in the bull: II. Proposal for a new classification of the spermiogram. Med Weter 4, 239-242 [in Polish]

Brito LFC (2007) Evaluation of stallion sperm morphology. Clin Techn Equine Pract 6, 249-264

Bronicka A, Dembiński Z (1999) Current criteria and conditions influencing the quality of boar semen. Med Weter 55, 436-439 [in Polish]

Casey PJ, Gravance CG, Davis RO, Chabot DD, Liu IKM (1997) Morphometric differences in sperm head dimensions of fertile and subfertile stallions. Theriogenology 47, 575-582

Clark SG, Schaeffer DJ, Althouse GC (2003) B-Mode ultrasonographic evaluation of paired testicular diameter of mature boars in relation to average total sperm numbers. Theriogenology 60, 1011-1023

Crabo BG (1997) Reproductive examination and evaluation of the boar. In: Youngquist RS (ed.) Current Therapy in Large Animal Theriogenology. WB Saunders Company, PA, USA, 664-670

Cummins JM, Woodall PF (1985) On mammalian sperm dimensions. J Reprod Fert 75, 153-175

Evenson DP, Wixon R (2006) Clinical aspects of sperm DNA fragmentation detection and male infertility. Theriogenology 65, 979-991

Ferrari MR, Spirito SE, Giuliano SM, Fernández HA (1998) Chromatin cytophotometric analysis of abnormal bovine spermatozoa. Andrologia 30, 85-89

Flowers WL (2008) Genetic and phenotypic variation in reproductive traits of Al boars. Theriogenology 70, 1297-1303

Gage MJG, Cook PA (1994) Sperm size or numbers? Effects of nutritional stress upon eupyrene and apyrene sperm production strategies in the moth Plodia interpunctella (Liepidoptera: Pyralidae). Funct Ecol 8, 594599

Gage MJG, Morrow EH (2003) Experimental evidence for the evolution of numerous, tiny sperm via sperm competition. Curr Biol 13, 754-757

Gil MC, García-Herreros M, Barón FJ, Aparicio IM, Santos AJ, García-Marín LJ (2009) Morphometry of porcine spermatozoa and its functional significance in relation with the motility parameters in fresh semen. Theriogenology 71, 254-263

Gomendio M, Roldan ER (1991) Sperm competition influences sperm size in mammals. Proc R Soc Lond B 243, 181-185 
Gomendio M, Roldan ER (1993) Coevolution between male ejaculates and female reproductive biology in eutherian mammals. Proc R Soc Lond B 252, 7-12

Gregor G, Hardge T (1995) The influence of gene variants at the Ryanodine-Receptor on sperm quality of boars. Arch Tierz 38, 527-538 [in German]

Hallap T, Nagy S, Håård M, Jaakma Ü, Johannisson A, Rodríguez-Martínez H (2005) Sperm chromatin stability in frozen-thawed semen is maintained over age in Al bulls. Theriogenology 63, 1752-1763

Hidalgo M, Rodríguez I, Dorado J, Soler C (2008) Morphometric classification of Spanish thoroughbred stallion sperm heads. Anim Repr Sci 103, 374-378

Hirai M, Boersma A, Hoeflich A, Wolf E, Föll J, Aumüller R, Braun J (2001) Objectively measured sperm motility and sperm head morphometry in boars (Sus scrofa): Relation to fertility and seminal plasma growth factors. J Androl 22, 104-110

Jacyno E, Kołodziej A, Kawęcka M, Pietruszka A, Matysiak B, Kamyczek M (2009) The relationship between blood serum and seminal plasma cholesterol content in young boars and their semen qualitative traits and testes size. Arch Tierz 52, 161-168

Jankevičiūtè N, Žilinskas H (2002) Influence of some factors on semen quality of different breeds of boars. Vet Zoot 19, 15-19 [in Lithuanian]

Karabinus DS, Evenson DP, Jost LK, Baer RK, Kaproth MT (1990) Comparison of semen quality in young and mature Holstein bulls measured by light microscopy and flow cytometry. J Dairy Sci 73, 2364-2371

Kawęcka M (2002) Relationships between cholesterol concentration in the blood serum of young boars of sire populations and their reproductive usefulness. Habil Thesis, AR Szczecin 206, Poland [in Polish]

Kawęcka M, Pietruszka A, Jacyno E, Czarnecki R, Kamyczek M (2008) Quality of semen of young boars of the breeds Pietrain and Duroc and their reciprocal crosses. Arch Tierz 51, $42-54$

King GJ, Macpherson JW (1973) A comparison of two methods for boar semen collection. J Anim Sci 64, 563565

Kondracki S, Banaszewska D, Wysokińska A, Kosieradzka J (2004) Effect of age on semen traits of young landrace boars. J Agrobiol Ecol 1, 112-117

Kondracki S, Banaszewska D, Mielnicka C (2005) The effect of age on the morphometric sperm traits of domestic pig (Sus scrofa domestica). Cell Mol Biol Lett 10, 3-13

Kondracki S, Banaszewska D, Wysokińska A, Sadowska A (2006) Ejaculate traits and spermatozoa morphology as related to spermatozoa concentration in ejaculates of Polish Large White boars. Anim Sci Pap Rep 24, Suppl 3, 111-119

Kumaresan A, Bujarbaruah KM, Kadirvel G, Khargharia G, Sarma RG, Goswami J, Basumatary R, Palaniappan K, Bardoloi RK (2011) Early sexual maturity in local boars of Northeastern India: Age-related changes in testicular growth, epididymal sperm characteristics and peripheral testosterone levels. Theriogenology 75, 687-695

Malo AF, Gomendio M, Garde J, Lang-Lenton B, Soler AJ, Roldan ERS (2006) Sperm design and sperm function. Biol Lett 2, 246-249

Ombelet W, Menkveld R, Kruger TF, Steeno O (1995) Sperm morphology assessment: historical review in relation to fertility. Hum Reprod Update 1, 543-57

Peña FJ, Saravia F, García-Herreros M, Núñez-Martínez I, Tapia JA, Johannisson A, Wallgren M, RodríguezMartínez H (2005) Identification of sperm morphometric subpopulations in two different portions of the boar ejaculate and its relation to postthaw quality. J Androl 26, 716-723

Quintero-Moreno A, González-Villalobos D, López-Brea JJG, Esteso MC, Fernández-Santos MR, CarvalhoCrociata JL, Mejia-Silva W, León-Atencio G (2009) Morphometric Evaluation of Sperm Head of Domestic Pig According their Age. Revista Científica FCV-LUZ 19, 153-158 [in Spanish]

Radwan J (1996) Intraspecific variation in sperm competition success in the bulb mite: a role for sperm size. Proc R Soc Lond B 263, 855-859

Sailer BL, Jost LK, Evenson DP (1996) Bull sperm head morphometry related to abnormal chromatin structure and fertility. Cytometry 24, 167-173 
Saravia F, Núñez-Martínez I, Morán JM, Soler C, Muriel A, Rodríguez-Martínez H, Peña FJ (2007) Differences in boar sperm head shape and dimensions recorded by computer-assisted sperm morphometry are not related to chromatin integrity. Theriogenology 68, 196-203

Sarder MJU (2008) Effects of age, body weight, body condition and scrotal circumference on sperm abnormalities of bulls used for artificial insemination (Al) programme in Bangladesh. Univ J Zool Rajshahi Univ 27, 73-78

Šernienė L, Riškevičienè V, Banys A, Žilinskas H (2002) Effects of age, and season on sperm qualitative parameters in Lithuanian White and Petren boars. Vet Zoot 17, 1-5

Shamsuddin M, Rodríguez-Martínez H, Larsson B (1993) Fertilizing capacity of bovine spermatozoa selected after swim-up in hyaluronic acid containing medium. Reprod Fertil Dev 5, 307-315

Shamsuddin M, Rodríguez-Martínez H (1994) A simple, non-traumatic swim-up method for the selection of spermatozoa for in vitro fertilization in the bovine. Anim Reprod Sci 36, 61-75

Smital J (2009) Effects influencing boar semen. Anim Reprod Sci 110, 335-346

Thurston LM, Watson PF, Mileham AJ, Holt WV (2001) Morphologically distinct sperm subpopulations defined by Fourier shape descriptors in fresh ejaculates correlate with variation in boar semen quality following cryopreservation. J Androl 22, 382-394

Received 19 October 2010, accepted 28 April 2011.

Corresponding author:

Stanisław Kondracki

email: sk@uph.edu.pl

Department of Animal Reproduction and Hygiene, Institute of Bioengineering and Animal Breeding, University of a Natural Sciences and Humanities in Siedlce, Prusa 14, 08-110 Siedlce, Poland 